\title{
Seasonality of respiration and ammonium excretion in the Antarctic echinoid Sterechinus neumayeri
}

\author{
Simon Brockington*, Lloyd S. Peck \\ Biological Sciences, British Antarctic Survey, High Cross, Madingley Road, Cambridge CB3 0ET, United Kingdom
}

\begin{abstract}
Oxygen consumption $\left(\mathrm{MO}_{2}\right)$ and ammonium excretion rates were recorded monthly over 2 yr for the regular Antarctic echinoid Sterechinus neumayeri to investigate metabolic activity in relation to seasonal food limitation (i.e. phytoplankton standing stock) at Adelaide Island $\left(67^{\circ} 34^{\prime} \mathrm{S}\right.$, $\left.68^{\circ} 07^{\prime} \mathrm{W}\right)$. Phytoplankton standing stock showed a brief but intense summer bloom and extended winter minima characteristic of Antarctic nearshore localities. Metabolic data were expressed for a standard sea urchin of $24.4 \mathrm{~mm}$ horizontal test diameter (this was the mean size of urchins used in the study). Two geographically close populations were studied, and strong seasonality was observed in $\mathrm{MO}_{2}$ at both sites. Mean austral winter minimal metabolic rates were 0.46 and $0.65 \mu \mathrm{mol} \mathrm{O}_{2}$ standard ind. ${ }^{-1} \mathrm{~h}^{-1}$ in 1997 and 1998 respectively at the main study site (North Cove). Mean winter oxygenconsumption rates at the second site (South Cove) were consistently lower throughout the study period (0.33 and $0.58 \mu \mathrm{mol} \mathrm{O} \mathrm{O}_{2}$ standard ind $\mathrm{.}^{-1} \mathrm{~h}^{-1}$ in 1997 and 1998 respectively), which coincided with reduced gonad mass in sea urchins from this site. The minimal winter metabolic rates persisted for 7 and 6 mo respectively. Changes in the organic mass (ash-free dry mass, AFDM) of a standard individual were also recorded mainly due to differences in reproductive condition, but also to seasonal accumulation and metabolic use of body reserves. Energy liberated by loss of AFDM in the winter period equated to a metabolic use of 64 to $432 \mathrm{~J} \mathrm{mo}^{-1}$, whereas winter $\mathrm{MO}_{2}$ values indicated a metabolic use of 102 to $180 \mathrm{~J} \mathrm{mo}^{-1}$. Maximal summer $\mathrm{MO}_{2}$ recorded was 1.44 and $1.62 \mu \mathrm{mol} \mathrm{O}$. standard ind.$^{-1} \mathrm{~h}^{-1}$ in the 1997/98 and 1998/99 summers respectively, indicating a factorial increase over winter oxygen consumption rates of $\times 3.1$ and $\times 2.5$. Rapid metabolic increases occurred at the end of the winter, and were closely coincident with the onset of the phytoplankton bloom despite $S$. neumayeri being a deposit feeder. These $\mathrm{MO}_{2}$ rates are amongst the lowest reported for echinoids. Ammonium excretion followed a similar seasonal cycle, with peak rates of 262 and $415 \mathrm{nmol} \mathrm{NH}_{4}^{+}$ standard ind.$^{-1} \mathrm{~h}^{-1}$ during the $1997 / 98$ and 1998/99 summer seasons, contrasting with winter mini-

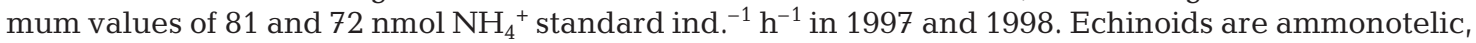
and O:N ratios varied between 7 and 26 during the study period. Lowest values, indicating proteinbased metabolism, were found at the immediate start of the austral summer. O:N ratios gradually increased during the summer and following winter, as lipid and carbohydrate became more important in fuelling metabolism. However, even at the highest ratios ( 25), protein still accounted for $50 \%$ of the metabolic substrate. The strong metabolic seasonality indicated by these data suggest that the generalistic deposit-feeding strategy employed by $S$. neumayeri does not exempt this species from the intense seasonal cycle of food availability (i.e. chlorophyll standing stock) at Antarctic nearshore locations.
\end{abstract}

KEY WORDS: Aerobic scope - Metabolic rate - Nitrogen excretion · O:N ratio · Oxygen consumption · Sea urchin · Polar winter

*E-mail: sbro@bas.ac.uk 


\section{INTRODUCTION}

Antarctic marine ectotherms live at low but fairly stable temperatures (annual variation typically less than $3^{\circ} \mathrm{C}$ ). Several studies of individual taxa have shown that they exhibit low resting metabolic rates (White 1975, Peck et al. 1987, Davenport 1988, Peck 1989, 1996, Chapelle \& Peck 1995, Ahn \& Shim 1998). Comparative studies indicate a positive relationship between water temperature and resting metabolic rate (Luxmoore 1984, Clarke 1991, Peck \& Conway 2000). Clarke \& Johnston (1999) showed that a typical tropical fish at $30^{\circ} \mathrm{C}$ requires approximately 6 times as much oxygen for resting metabolism as does a polar fish at $0^{\circ} \mathrm{C}\left(Q_{10}=1.83\right)$. The lowered metabolic rate of these Antarctic ectotherms has been suggested to be a consequence of reduced basal costs, of which protein turnover appears to be a major component (Clarke 1998). Such reduced costs could influence the relative growth efficiencies of polar species and may also be significant for the survival of polar benthos during the energy-limited austral winter.

A consequence of reduced resting metabolic rates may, however, be a diminished capacity for power generation (aerobic scope) in polar species. The maximum level of activity attained by an organism is linked factorially to its resting metabolic rate, and for sessile or slow moving ectotherms it is usually in the range of $\times 2$ to $\times 4$ (Peck 1998). Because of the underlying effect of temperature on resting metabolic rate, the same factorial increase will result in a greatly reduced absolute metabolic rise for a cold-water species compared with a similar species from warmer water. In this context, seasonal variations in the metabolism of polar marine invertebrate populations are of interest.

Food availability to the benthic community (as estimated by autotrophic biomass) varies strongly with season in Antarctic nearshore locations because of the sharp reduction in solar insolation in winter months at high latitudes (Clarke 1998, Clarke et al. 1988, Karl et al. 1991, Clarke \& Leakey 1996). The austral winter is therefore an energy-limited period, and some (though not all) benthic species cease feeding for varying lengths of time (Barnes \& Clarke 1994, 1995). Brockington et al. (2001) showed that Sterechinus neumayeri ceased feeding for between 4 and 7 mo during the austral winter at Rothera Point, Adelaide Island, and that $84 \%$ of the total annual faecal egestion took place during the pelagic bloom period in the austral summer. During winter, polar species must therefore survive on body reserves, a strategy which is possible because of the low metabolic rates exhibited by polar benthos (Clarke \& Peck 1991). However the period of reduced food availability may be lengthy, and data are not available to relate observed metabolic energy demand under starvation to body-mass loss for any benthic Antarctic ectotherms.
The aim of this study was to document seasonal variation in oxygen consumption $\left(\mathrm{MO}_{2} \mu \mathrm{mol} \mathrm{h}^{-1}\right)$ for the common Antarctic sea urchin Sterechinus neumayeri over a 2 yr period. This enabled comparison with echinoid oxygen-consumption rates from temperate and tropical latitudes, and also provided a field-derived factorial and seasonal aerobic scope. Oxygen consumption was compared with loss of standard individual mass during the period of winter starvation via an oxycalorific coefficient. Rates of ammonium excretion $\left(\mathrm{NH}_{4}^{+} \mu \mathrm{mol} \mathrm{h}^{-1}\right)$ were also determined over the same period, and comparisons of atomic oxygen:nitrogen (O:N) ratios were used to give an indication of metabolic substrate utilised.

\section{METHODS}

Fieldwork for this study was carried out in the Bonner Laboratory at the British Antarctic Survey's Rothera Research Station on Adelaide Island (67²34' S, $68^{\circ} 07^{\prime} \mathrm{W}$ ) between February 1997 and January 1999 (Fig. 1). Sterechinus neumayeri is particularly abundant near Rothera Station, reaching maximal densities of 223 ind. $\mathrm{m}^{-2}$ (Brockington unpubl. data). Two geographically close sites were contrasted because sea urchins from each location differed markedly in reproductive

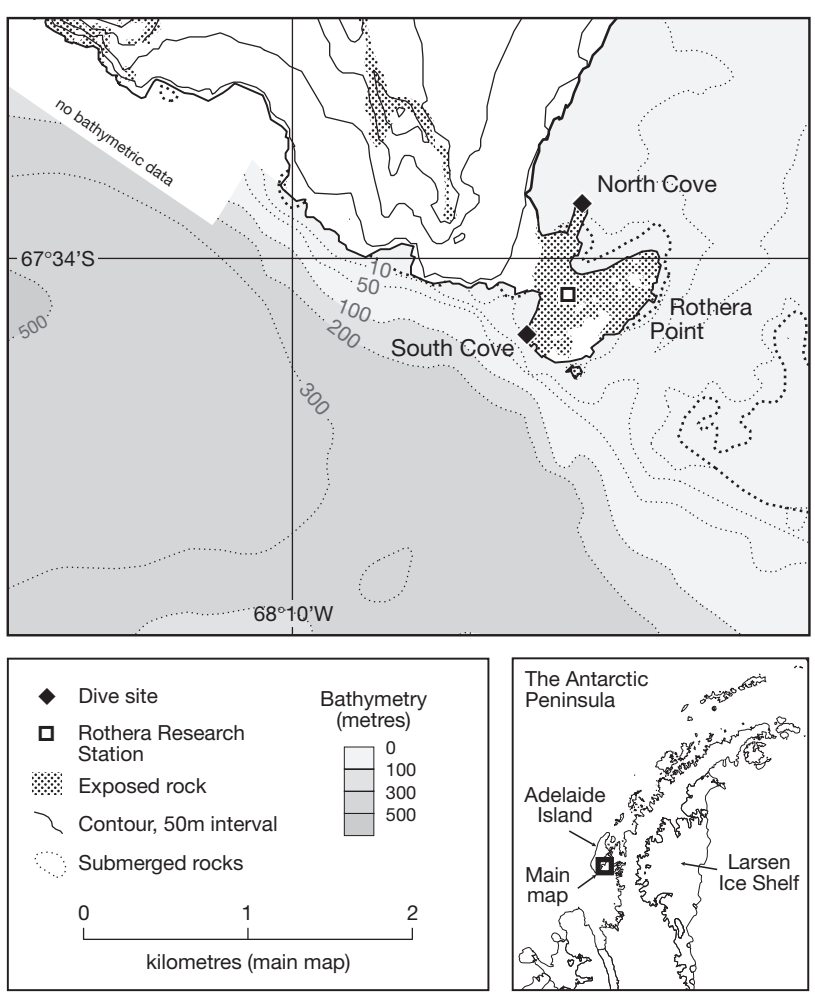

Fig. 1. Map of Rothera Point, Adelaide Island, showing locations of North and South Cove sampling sites in relation to the British Antarctic Survey Research Station 
condition throughout the study period. The first sampling site (North Cove) was at $30 \mathrm{~m}$ depth in North Cove on a sediment substratum. The second site (South Cove) was $1 \mathrm{~km}$ to the south at 6 to $10 \mathrm{~m}$ depth on hard rock at Honeybucket Island. Sea urchins were collected using SCUBA, with access from the shore in summer and through holes cut in the sea-ice during winter. After collection, specimens were returned quickly to the Bonner Laboratory, where they were carefully sorted and any adherent material removed. They were held in gently running seawater overnight in a flow-through aquarium to allow time for recovery from handling before metabolic measures were taken. Oxygen consumption $\left(\mathrm{MO}_{2}\right)$ and ammonium excretion rates were measured simultaneously on the same individuals to allow calculation of O:N ratios. The non-feeding period, based on gut-content analysis, for this species for each austral winter was between May and December 1997 and between May and September 1998 (Brockington et al. 2001). Specimens returned to the laboratory during this time showed very low locomotor activity.

Measurements of both $\mathrm{MO}_{2}$ and ammonium excretion were conducted monthly, using 24 individuals from North Cove (the main study site), and 8 from South Cove. A wide size range of sea urchins was assessed each month and the overall study size range was 3.8 to $59.9 \mathrm{~mm}$. After respiration and ammonium excretion measurements were completed, the test diameter of each individual was measured in 3 horizontal directions and a mean value calculated. Dry mass was then determined for whole sea urchins using the entire body including gut contents, after drying to a constant mass at $60^{\circ} \mathrm{C}_{i}$ ash-free dry mass (AFDM) was obtained by difference following ignition of the entire body (and gut contents) at $465^{\circ} \mathrm{C}$ for $22 \mathrm{~h}$. The biomass to diameter relationship (using AFDM for biomass due to the large percentage of inorganic material present in echinoids) was then calculated for each site for each month.

Couloximetric measurement of $\mathbf{M O}_{2} \cdot \mathrm{MO}_{2}$ values were assessed using closed-chamber respirometry techniques similar to those described by Chapelle \& Peck (1995), and individual $\mathrm{MO}_{2}$ was obtained by comparisons with control chambers (no sea urchin). Three sizes of respirometer $(60,80$ or $180 \mathrm{ml})$ were used, and incubation times were adjusted to allow for variations in $\mathrm{MO}_{2}$ arising from body size and time of year. The $\mathrm{MO}_{2}$ rate of Sterechinus neumayeri is independent of falling environmental oxygen concentration down to a tension of $50 \mathrm{~mm} \mathrm{Hg}$, indicating that closed-chamber respirometry methods are fully appropriate for this species (Brockington unpubl. data). The oxygen tension in the chambers was not allowed to fall below $100 \mathrm{~mm} \mathrm{Hg}$ during this study. Two replicate measures were made from each respirometer, and $\mathrm{MO}_{2}$ was calculated after a correction of the respirometer volume for water displaced by the urchin.

Chambers were inverted carefully 3 times at the end of each trial to ensure adequate mixing, and replicate $25 \mu \mathrm{l}$ samples of water were withdrawn using a gastight syringe through a septum, and injected into a couloximeter (Peck \& Uglow 1990) to measure oxygen content. The small sample method used here has an advantage over traditional polarographic systems which require animals to be held in relatively large volumes of seawater; this has important implications for the measurement of the very low $\mathrm{MO}_{2}$ rates often exhibited by polar benthic invertebrates.

Ammonium excretion. Immediately after oxygen measurements were completed, the respirometer lid was removed and $10 \mathrm{ml}$ aliquots of water were transferred to duplicate teflon tubes (i.e. 2 tubes each containing $10 \mathrm{ml}$ ) for ammonium analysis. Ammonium levels in the seawater were determined spectrophotometrically using the phenol hypochlorite method of Solórzano (1969) as modified by Liddicoat et al. (1975) and Clarke et al. (1994). The incubation stage of the assay was also modified according to Catalano (1987) by using teflon tubes and tungsten illumination. The assay was calibrated by spiking seawater with ammonium sulphate, and the background ammonium concentration in seawater controls was subtracted from the experimental values. As for $\mathrm{MO}_{2}$, ammonium excretion rates were calculated after correction of chamber volume for the displacement of the sea urchin.

Chlorophyll standing stock. Seawater chlorophyll standing stock was measured weekly as part of a longterm monitoring programme at Rothera Station. Water samples were collected from $15 \mathrm{~m}$ depth using a handheld plastic water corer, and returned to the laboratory in polythene bottles. After gentle agitation the samples were fractionated using a succession of filters (20 to $0.2 \mu \mathrm{m}$ ) under gravity and in the dark. Chlorophyll was extracted from the retained particulate matter with a mixture of 2:1 chloroform:methanol, and subsequently assayed fluorometrically using a Turner fluorometer calibrated against a chlorophyll standard extracted from Anacystis nidulans (Sigma-Aldrich).

Statistical analysis of data. Data were analysed using multiple regression and ANOVA, performed using Statistical Analysis Software, Version 6.12 for Windows (SAS Institute Inc. 1998).

\section{RESULTS}

\section{Autotrophic standing stock}

The strong seasonality of phytoplankton standing stock recorded at Rothera (Fig. 2) is likely to have 


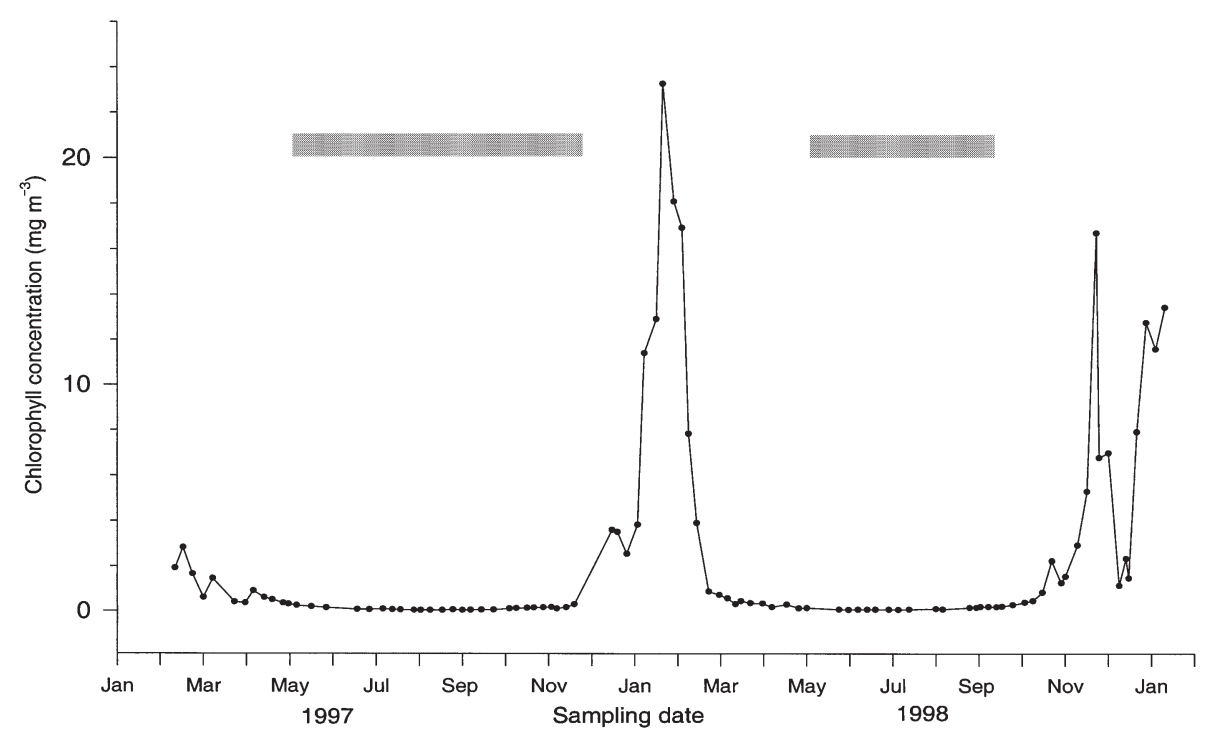

Fig. 2. Seasonal variations in total water-column chlorophyll a near Rothera Research Station between February 1997 and January 1999. Water samples were collected from $15 \mathrm{~m}$ depth in Ryder Bay, and each point is the mean of 3 separate measurements from a single bottle sample (data from Rothera Time Series monitoring programme). Shaded bars represent Sterechinus neumayeri's non-feeding period determined by Brockington et al. (2001)

important implications for benthic suspension feeders and, via vertical flux, also for generalists and deposit feeders. A single intense bloom was recorded at the start of the 1997/98 austral summer which developed in early January, the onset coinciding with the breakout time of the winter fast-ice. At its peak, this bloom reached a chlorophyll concentration of over $24 \mathrm{mg} \mathrm{m}^{-3}$, which contrasted with the less intense early and late summer blooms (15 to $20 \mathrm{mg} \mathrm{m}^{-3}$ ) in 1998/99. The development of fast-ice during the 1998 winter was on a considerably smaller scale than that in 1997, and it is likely that the extra light penetrating the water column in 1998 allowed for the earlier development of the phytoplankton bloom in November. Low winter chlorophyll concentrations (in the range 0.05 to $0.2 \mathrm{mg} \mathrm{m}^{-3}$ ) persisted for $142 \mathrm{~d}$ in 1997 and $159 \mathrm{~d}$ in 1998.

\section{Echinoid AFDM}

A total of 723 measurements of the AFDM of Sterechinus neumayeri were made during the 25 mo study period, over a total size range of 3.8 to $59.9 \mathrm{~mm}$ test diameter (mean = $24.4 \mathrm{~mm}, \mathrm{SD}=8.6 \mathrm{~mm})$. Data were expressed for a standard individual of $24.4 \mathrm{~mm}$ test diameter, which was the mean size of the sea urchins used. Standard individual values were obtained following double $\log _{\mathrm{e}}$-transformed regressions of AFDM versus test diameter (Fig. 3).

Multiple regression and ANOVA provided a good fit to both the North and South Cove data (overall fits: North Cove $F=2653$, $\mathrm{p}<0.0001$; South Cove $F=1468$, $\mathrm{p}<0.0001)$ and indicated that echinoid AFDM was higher in 1998 than 1997 at both sites (North Cove $F=4.086, \mathrm{p}=0.044$, South Cove $F=4.194, \mathrm{p}=0.042$ ). The same technique also indicated that the North Cove sea urchins had a significantly greater AFDM in both years than the South Cove sea urchins $(F=26.89, \mathrm{p}<0.0001)$.

Changes in echinoid AFDM during the non-feeding period were estimated from the multiple regression and ANOVA model. In May 1997 the AFDM of a standard $24.4 \mathrm{~mm}$ test-diameter individual at North Cove was $0.362 \mathrm{~g}$, which had decreased to $0.345 \mathrm{~g}$ by December (a drop of $0.003 \mathrm{~g} \mathrm{mo}^{-1}$ over the winter non-feeding period). For 1998 (North Cove), the decrease between May and

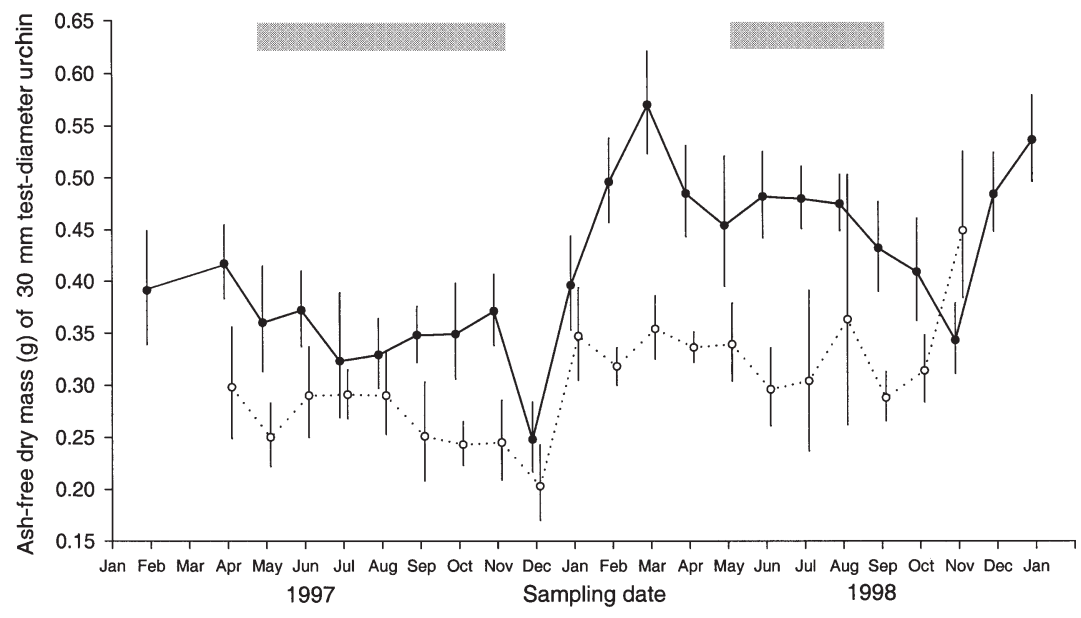

Fig. 3. Sterechinus neumayeri. Organic mass (ash-free dry mass) of a standard $30 \mathrm{~mm}$ test-diameter sea urchin plotted for the duration of the study period for samples from $30 \mathrm{~m}$ depth on sediment substratum at North Cove (•) and 6 to $10 \mathrm{~m}$ depth on a rock substratum at South Cove (0). Plotted results are from regressions of $\log _{\mathrm{e}}$-transformed data for mass against test diameter $\left(\mathrm{n}=24 \mathrm{mo}^{-1}\right.$ for North Cove, and $\mathrm{n}=8 \mathrm{mo}^{-1}$ for South Cove). Error bars represent $95 \%$ confidence intervals of the regressions, larger positive intervals are due to the use of logarithmic transformations. Shaded bars represent $S$. neumayeri's nonfeeding period determined by Brockington et al. (2001) 
September was from 0.508 to $0.433 \mathrm{~g}$ for the same testdiameter individual $\left(0.019 \mathrm{~g} \mathrm{mo}^{-1}\right)$. For South Cove, the decrease in mass over the same periods was 0.006 and $0.011 \mathrm{~g} \mathrm{mo}^{-1}$ for 1997 and 1998 respectively (Table 1).

\section{Seasonal $\mathrm{MO}_{2}$}

Standard individual $\mathrm{MO}_{2}$ rates rose rapidly at the end of the austral winter period, coinciding exactly with the onset of the phytoplankton bloom. They then remained high during the feeding period described by Brockington et al. (2001) in both years (Fig. 4). Rates of $\mathrm{MO}_{2}$ decreased after the summer peak as feeding activity and phytoplankton standing stock also de-

Table 1. Sterechinus neumayeri. Comparison of energy available from loss of standard individual ash-free dry mass (AFDM) during non-feeding period of austral winter with metabolic energy use (calculated via an oxycalorific coefficient from winter respiration rate). Energy liberated per month is in broad agreement with heat dissipated

\begin{tabular}{|c|c|c|c|c|c|}
\hline $\begin{array}{l}\text { Year, } \\
\text { Site }\end{array}$ & $\begin{array}{l}\text { Non-feeding } \\
\text { period }^{a} \\
(\mathrm{mo})\end{array}$ & $\begin{array}{c}\text { Reduction in } \\
\text { AFDM } \\
\left(\mathrm{g} \mathrm{mo}^{-1}\right)\end{array}$ & $\begin{array}{l}\text { Energy } \\
\text { liberated } \\
\left(\mathrm{J} \mathrm{mo}^{-1}\right)\end{array}$ & $\begin{array}{c}\text { Mean molar oxygen } \\
\text { consumption (winter) } \\
\left(\mu \mathrm{mol} \mathrm{mo} \mathrm{m}^{-1}\right)\end{array}$ & $\begin{array}{c}\text { Heat } \\
\text { dissipated } \\
\left(\mathrm{J} \mathrm{mo}^{-1}\right)\end{array}$ \\
\hline \multicolumn{6}{|l|}{1997} \\
\hline North & 6 & 0.003 & 64 & 336 & 145 \\
\hline South & 6 & 0.006 & 138 & 236 & 102 \\
\hline \multicolumn{6}{|l|}{1998} \\
\hline North & 4 & 0.019 & 432 & 471 & 204 \\
\hline South & 4 & 0.011 & 242 & 418 & 181 \\
\hline
\end{tabular}

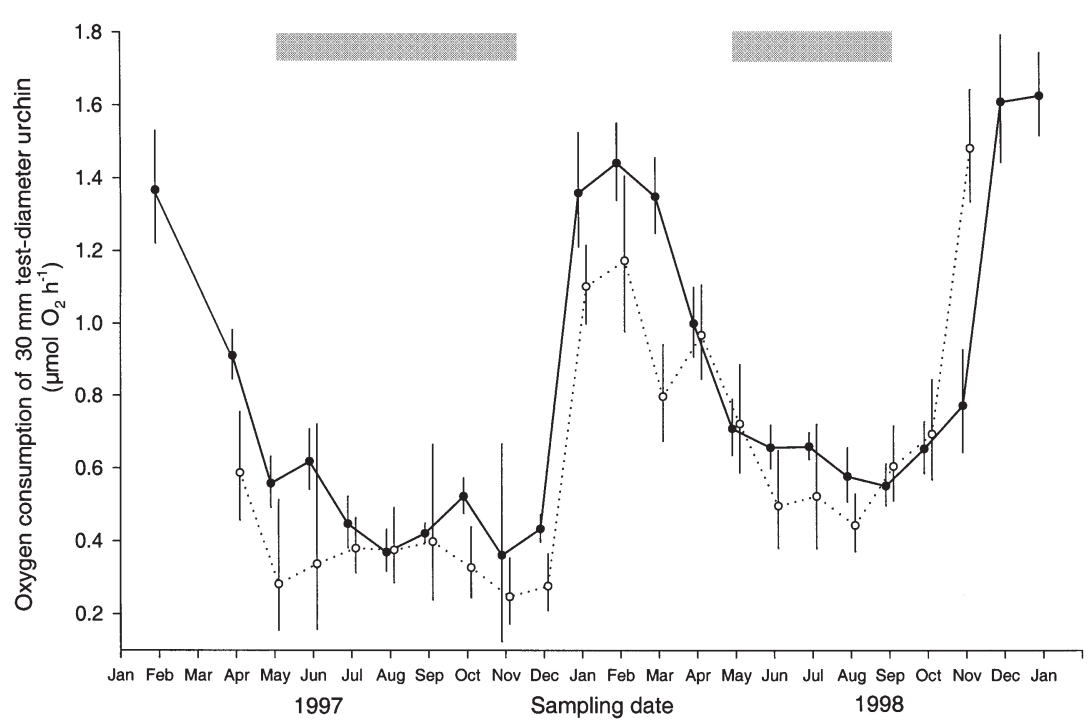

Fig. 4. Sterechinus neumayeri. Molar oxygen consumption $\left(\mathrm{MO}_{2}\right)$ rates for a standard $30 \mathrm{~mm}$ test-diameter sea urchin from North $(\bullet)$ and South Cove (०). Plotted results are from $\log _{\mathrm{e}}$-transformed data for $\mathrm{MO}_{2}$ against test diameter $\left(\mathrm{n}=24 \mathrm{mo}^{-1}\right.$ for North Cove, and $\mathrm{n}=8 \mathrm{mo}^{-1}$ for South Cove). Further details as in legend to Fig. 3 creased, and minimum winter $\mathrm{MO}_{2}$ values (non-feedstate) were recorded for 7 mo in the 1997 winte biomass, $\mathrm{MO}_{2}$ was adequately described r a model using multiple linear regression and tween May and December in 1997 and May to NoNorth Cove $=0.46 \mu \mathrm{mol} \mathrm{O} \mathrm{h}^{-1}$ in winter 1997, and $0.65 \mu \mathrm{mol} \mathrm{O} \mathrm{O}_{2} \mathrm{~h}^{-1}$ in winter 1998. Thus the factorial increase in metabolic rate between winter and summer was $\times 3.1$ for 1997, and $\times 2.5$ for 1998 at North Cove. Factorial increases for South Cove calculated in the same way are of similar magnitude; $\times 3.6$ for 1997 and $\times 2.6$ for 1998 .

\section{Seasonal ammonium excretion and oxygen:nitrogen $(\mathrm{O}: \mathrm{N})$ ratio}

Strong seasonal and interannual variation also occurred in ammonium excretion (Fig. 5). The multiple regression and ANOVA model again provided a good fit to the data $(F=280.6, \mathrm{p}<0.0001)$, but indicated no differences between sites $(F=0.328, \mathrm{p}=0.567)$. Large between-year differences were evident in the magnitudes of the summer maxima recorded (262 $\mathrm{nmol} \mathrm{NH}_{4}{ }^{+}$ standard ind. ${ }^{-1} \mathrm{~h}^{-1}$ in the 1997/98 summer, and $415 \mathrm{nmol} \mathrm{NH}_{4}{ }^{+}$ standard ind. ${ }^{-1} \mathrm{~h}^{-1}$ in the 1998/99 summer). Winter excretion levels were very similar for both years (mean $=76.6 \mathrm{nmol} \mathrm{NH}_{4}{ }^{+}$standard ind. $^{-1} \mathrm{~h}^{-1}$ ).

Regressions of O:N ratio against echinoid diameter were not significant for any of the months investigated. The $\mathrm{O}: \mathrm{N}$ ratio was always in the range of 5 to 26 (Fig. 6). The peak in ammonium excretion at the end of the austral winter period took place before the peak in $\mathrm{MO}_{2}$, and hence 


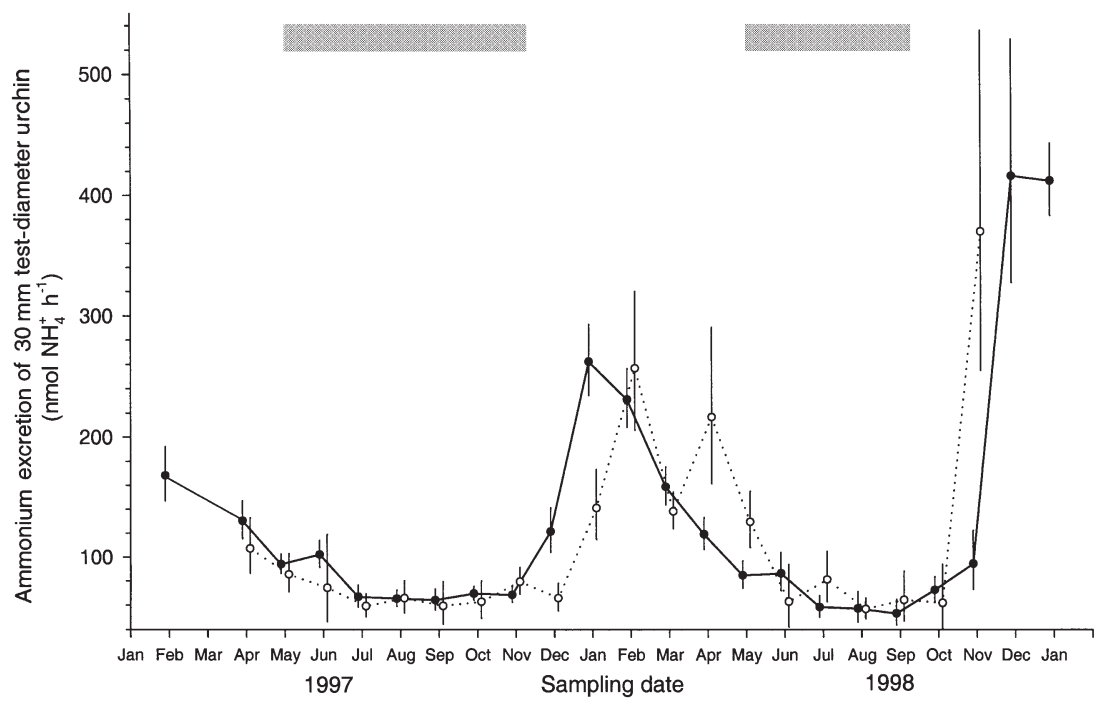

Fig. 5. Sterechinus neumayeri. Ammonium excretion rates for a standard $30 \mathrm{~mm}$ test-diameter sea urchin from 2 sites. Values were calculated from regressions of $\log _{\mathrm{e}}$-transformed data and are presented as for Fig. 4. Further details as in legend to Fig. 3

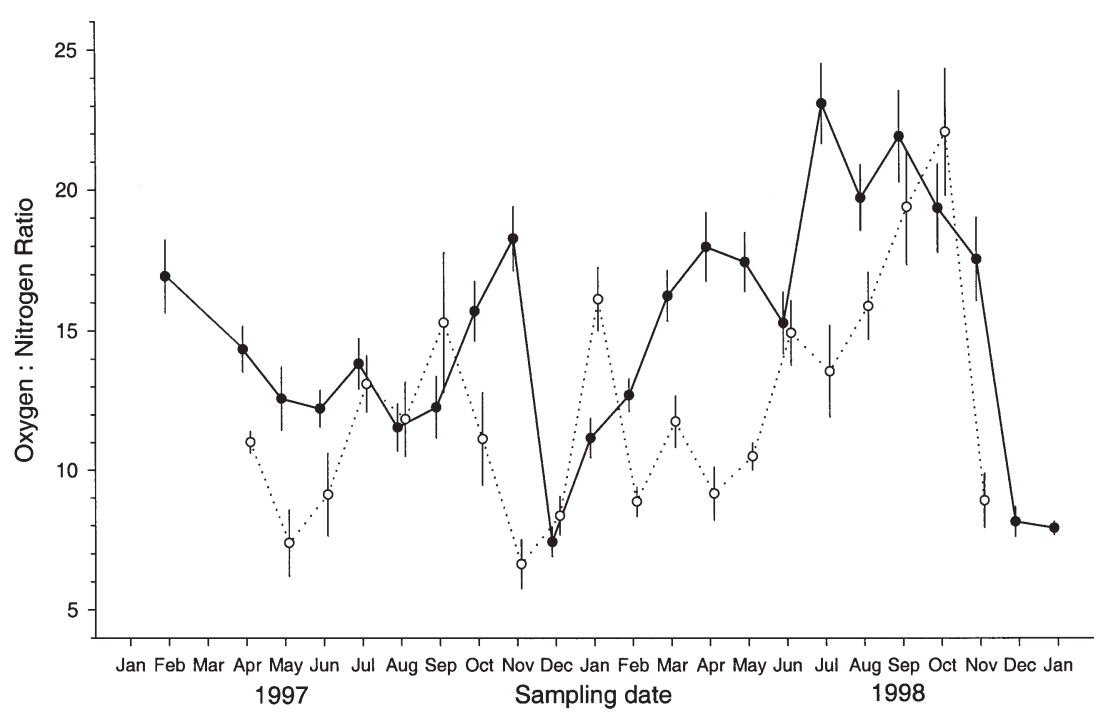

Fig. 6. Sterechinus neumayeri. O:N ratios for North $(\bullet)$ and South Cove (o) sea urchins. O:N ratio was calculated as ng-at oxygen consumed ind.$^{-1} \mathrm{~h}^{-1}$ divided by nmol ammonium excreted $\mathrm{h}^{-1}$. To convert from $\mu \mathrm{mol} \mathrm{O}_{2}$ to ng-atoms multiply by 2000 . Regressions of O:N ratio against urchin size (test diameter) were not significant for any of the monthly samples. Data always fall in the range 5 to 26 , indicating a protein-based metabolism, although pronounced decreases in the ratio are apparent at both sites during the early austral summer

the lowest ratios ( 7 to 8 ) were recorded early in the austral summer (December) at the end of both 1997 and 1998. These lows were followed by small rises during the remaining summer and winter periods. This pattern was clearer at both sites during the 1998 winter than in 1997.

\section{DISCUSSION}

\section{Environmental seasonality}

The strong seasonal variability in water-column autotrophic standing stock recorded here is consistent with patterns found at other Antarctic locations (Clarke 1988, Rivkin 1991, Clarke \& Leakey 1996). The intense bloom lasted a few weeks during the austral summer, and was contrasted by a greatly reduced phytoplankton standing stock throughout the winter months. Plankton produced in the pelagic zone is the basis of many benthic food webs (Graf 1992), and advection or flux of material from the pelagic to the benthic environment can take place over a short timescale (Bodungen et al. 1985, Bathmann et al. 1991, Karl et al. 1991). The strong seasonal variation in food availability to the benthos is contrasted by minimal fluctuations in temperature at polar latitudes. At Rothera, the seawater temperature varied between -1.8 and $+1.2^{\circ} \mathrm{C}$ during this study. Brockington \& Clarke (2001) recorded the metabolic cycle of starved Sterechinus neumayeri exposed to natural variations in temperature in the absence of food, and found that temperature alone accounted for only $17 \%$ of the summer metabolic rise whereas $83 \%$ was caused by increased physiological activity (i.e. feeding, growth and spawning) associated with the intense phytoplankton bloom.

\section{$\mathrm{MO}_{2}$ and echinoid biomass in relation to polar seasonality}

The $\mathrm{MO}_{2}$ rate of Sterechinus neumayeri had prominent summer peaks in $\mathrm{MO}_{2}$ and prolonged winter minima, which reflects closely phytoplankton abundance in both form and timing. $S$. neumayeri is a generalistic feeder (McClintock 1994). Such a strategy has been suggested to increase fitness by allowing feeding over a much longer period (Dell 1972). Echinoids from the North Cove study site were observed to feed only on sediment, whereas those from South Cove had a more varied diet including sediment, macroalgae, bryozoan 
fragments, crustaceans and also seal faeces (Brockington et al. 2001). Feeding (measured as rate of faecal egestion) took place only during the period of the pelagic bloom, and indicated that $S$. neumayeri was reliant on downward flux and advection of settled phytoplankton for a substantial part of its energy intake. The strong annual variability in $\mathrm{MO}_{2}$ was shown by echinoids from both populations, despite the broader diet of the South Cove population. This indicates that a greater breadth of diet did not support higher metabolic rate beyond the duration of the summer phytoplankton bloom.

A complete cessation of feeding was recorded for Sterechinus neumayeri for a $7 \mathrm{mo}$ period in winter 1997, and for 4 mo in winter 1998 (Brockington et al. 2001). During such periods, metabolism must be fuelled by body reserves. The data presented here indicate that biomass was lost by a standard $24.4 \mathrm{~mm}$ urchin in the non-feeding winter period at a rate of 2.8 to $18.8 \mathrm{mg} \mathrm{mo}^{-1}$. The strong contrast in standard individual AFDM between sites was related to differences in reproductive condition of the 2 populations: Brockington (unpubl. data) found that individuals from the North Cove site exhibited a higher gonad index $(\sim \times 3)$ than those from South Cove despite their narrower diet. Release of gametes takes place at the start of the austral summer, although gonad maturation occurs throughout the year (Pearse \& Giese 1967, Brockington pers. obs.), indicating that over wintering reduction in biomass resulted from metabolic demands alone. The energy content of macrobenthic aquatic invertebrate tissue has been summarised by Brey et al. (1988), who suggest that a conversion factor of $23 \mathrm{~kJ} \mathrm{~g}^{-1}$ AFDM may be used to convert mass data to energy. Using this conversion, the amount of energy liberated by the reduction of standard individual biomass in the winter non-feeding period was between 64.4 and $432 \mathrm{~J} \mathrm{mo}^{-1}$ (Table 1).

The power generation during the nonfeeding period of the austral winter may also be calculated from $\mathrm{MO}_{2}$ via the use of an oxycalorific coefficient. Brafield \& Llewellyn (1982) provide data for oxycalorific coefficients for different metabolic substrates. An appropriate conversion is $0.434 \mathrm{~J} \mu \mathrm{mol} \mathrm{O}_{2}$ based on substrate utilisation, as indicated by the mean winter $\mathrm{O}: \mathrm{N}$ ratio. These data are compiled for periods when feeding is entirely absent. The agreement of these 2 energy use estimates (mass loss and
$\mathrm{MO}_{2}$ ) suggest that it is unlikely that the echinoids derived any significant nutritional benefit from other sources (e.g. dissolved organic compounds) during the austral winter. The rate of loss of AFDM by Sterechinus neumayeri during the non-feeding periods is low. Lares \& Pomory (1998) demonstrated that Lytechinus variegatus lost $30 \%$ of its initial total organic content during $10 \mathrm{wk}$ starvation, and that the maximum time that $L$. variegatus can survive without food is $\sim 90 \mathrm{~d}$. In contrast, $S$. neumayeri from the North Cove site lost 4.6 and $14.8 \%$ of its initial AFDM during the 1997 and 1998 winters.

Antarctic fishes (Clarke \& Johnston 1999) and bivalve molluscs (Peck \& Conway 2000) have lower metabolic rates than similar species from temperate or tropical environments. The metabolic rates found here for Sterechinus neumayeri are at similar levels to those recorded by Belman \& Giese (1974) working on the same species, although their use of wet mass precludes accurate comparison with the data presented by this study. Although the scatter in the data is wide, the respiratory rate of echinoids increases with increasing temperature (Fig. 7), and S. neumayeri has one of the lowest rates reported for any sea urchin. This finding agrees with that of Féral \& Magniez (1988), who also

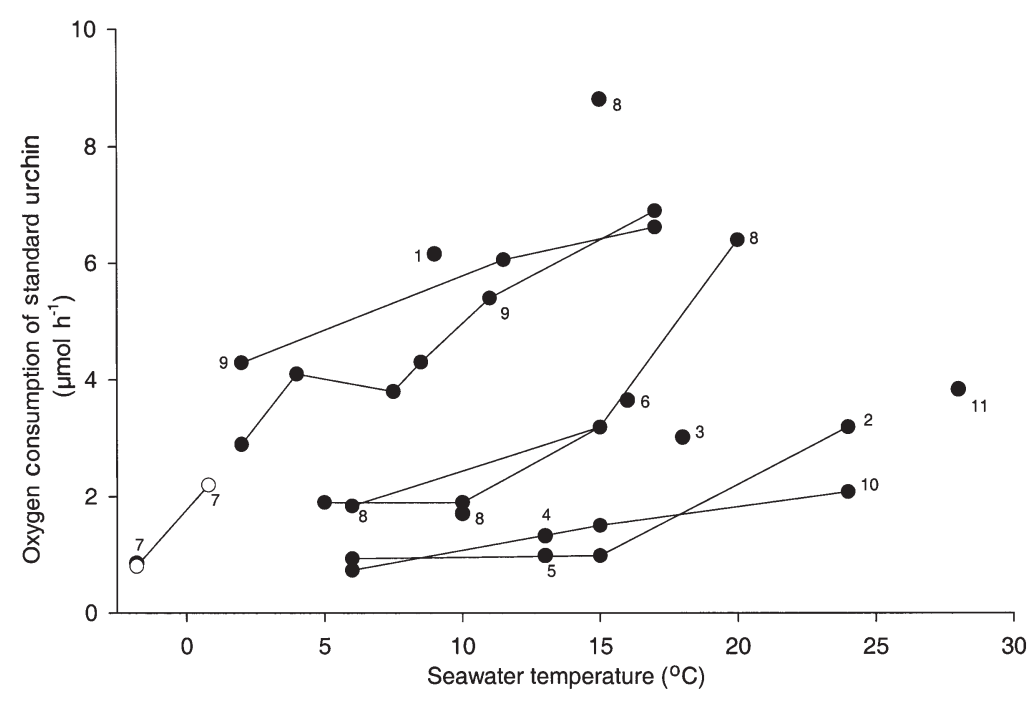

Fig. 7. Plot of respiratory rate of various echinoids against environmental temperature. Data compiled from Féral \& Magniez (1988) and from summary in Lawrence \& Lane (1982). 1: Abatus cordatus; 2: Allocentrotus fragilis; 3: Arbacia lixula; 4: Evechinus chloroticus; 5: Goniocidaris umbraculum; 6: Lytechinus anamesus; 7: Sterechinus neumayeri; 8: Stronglyocentrotus purpuratus; 9: Stronglyocentrotus droebachiensis; 10: Stronglyocentrotus francisanus; 11: Tripneustes ventricosus. Data converted to $\mu \mathrm{mol} \mathrm{O}_{2} \mathrm{~h}^{-1}$ where necessary, and corrected to a standard individual of $30 \mathrm{~mm}$ test diameter, $5.5 \mathrm{~g}$ wet mass, $2.3 \mathrm{~g}$ dry mass or $0.7 \mathrm{~g}$ ash-free dry mass. Single data points indicate individual determinations for a species at ambient temperature, points linked by lines indicate studies for a single species over a range of temperatures. (o) Data for $S$. neumayeri from this study. The overall trend is for increasing oxygen consumption with increasing environmental temperature 
showed a decrease in metabolic rate for echinoids with decreasing environmental mean seawater temperature. Such findings contrast with predictions that the mitochondrial proliferation observed in polar species (Johnston et al. 1994, 1998, Guderley 1998) should lead to elevated resting metabolic rates due to increased costs of mitochondrial maintenance at low temperatures (Pörtner et al. 1998). The reduced whole organism metabolic rate in comparison with that of warmerwater species helps to explain the considerably reduced rate of consumption of body reserves under polar conditions.

Aerobic factorial scope is the maximum increase in metabolic rate over resting displayed by a species. Basal metabolic rates are reduced under polar conditions, and consequently a fixed factorial scope will result in a greatly reduced absolute power generation for cold-water species compared to similar warmwater forms. The specific dynamic action of feeding (SDA) response may be indicative of maximum metabolic (aerobic) capacity for sessile or sluggish marine ectotherms (Peck 1998). The rise in metabolic rate following consumption of a meal is associated with the costs of processing the meal and consequent growth, and in echinoids may comprise an anaerobic component due to a poor internal circulatory system (Bookbinder \& Shick 1986). SDA factorial responses are independent of habitat temperature, although under polar conditions the duration of the response is extended, allowing the total extent of the SDA response to remain constant at different ambient temperatures. Peak factorial scopes determined from investigation of the SDA response are in the range of 1.6 to 2.5 times pre-feeding levels for sedentary polar species (Peck 1998). These estimates correlate well with the $\times 2.4$ to $\times 3.8$ seasonal rise in metabolism for Sterechinus neumayeri determined in this study.

Despite their inherent stenothermy, many members of the Antarctic benthos show normal responses to temperature (measured as $Q_{10}$ ) over the range they normally encounter (White 1975, Ralph \& Maxwell 1977, Ikeda \& Hing Fay 1981, Peck 1989, Pörtner et al. 1999). These $Q_{10}$ values are in the range of 2 to 3 , and may be applied to the winter resting metabolic rates derived by this study to estimate the increase in basal rate which may be expected due to the warmer seawater temperatures of the austral summer. Assuming a $Q_{10}$ of 2.5 , the change in temperature from -1.8 to $+1.2^{\circ} \mathrm{C}$ recorded at Rothera during this study would result in a summer increase over winter metabolic rates of $\times 1.3$; compared with observed increases in field rates of $\times 2.4$ and $\times 3.8$ in 1997 and 1998 at North Cove. Accurate calculation of the summer basal metabolic rate is confounded by concomitant changes in mass of the standard-sized individual in the transition to the summer period. Without correcting for mass, the rise of $\times 1.3$ due to temperature accounts for $13 \%$ of the summer respiratory rise in 1997/98 (compared to the 1997 winter) and $21 \%$ in 1998/99 (compared to the 1998 winter) at North Cove. The data therefore support the conclusion of Clarke (1993), and indicate that the slight seasonal elevations in temperature encountered at polar latitudes have only a minor influence upon the seasonal oxygen demand.

\section{Nitrogen excretion}

Although many echinoderms excrete some nitrogen as urea, echinoids are ammonotelic (Jangoux 1982, Stickle 1988). The major route for ammonium formation is through catabolism of both ingested and cellular protein. A seasonally changing pattern of ammonia excretion in relation to food availability was recorded for the ophiuroid Ophiothrix fragilis by Davoult et al. (1991), who found a $\times 2.7$ increase in the rate of ammonium excretion in summer compared to winter. Nitrogen excretion has been more intensively studied for bivalve molluscs, where again the major nitrogen product is ammonium. Significant seasonal changes in ammonium excretion were recorded for the temperate bivalve Mytilus edulis by Bayne \& Scullard (1977). These were interpreted as responses to the seasonal gametogenic cycle and of the metabolic effects of changes in ration size and quality. For Sterechinus neumayeri, the very strong seasonal cycle of excretion provides a second method for evaluating the effects of intense seasonal food limitation under polar conditions. As for respiration, excretion of ammonium by $S$. neumayeri increases during the summer, although the timings of the changes in ammonium excretion do not exactly coincide with changes in $\mathrm{MO}_{2}$, giving rise to a seasonal variation in O:N ratio.

\section{O:N ratio}

Theoretical values for the ratio were calculated by Ikeda (1977) as 415 to oxidise pure lipid, falling to 6.8 for pure protein; intermediate values around 25 indicate $50 \%$ protein utilisation. Values less than 7 were found by Peck et al. (1987) and Peck (1996) for Antarctic brachiopods. Values down to 3 may be explained by differences in the $\mathrm{C}: \mathrm{N}$ ratio of the particular protein (Mayzaud \& Conover 1988). Some further additional variation will exist if nitrogen excretion and $\mathrm{MO}_{2}$ for a given activity or process do not occur simultaneously.

The strikingly low values encountered in both years in the early part of the austral summer are indicative of 
a metabolic substrate derived almost solely from protein. During the winter period the O:N ratio rose slightly, suggesting that although protein was still providing the major metabolic substrate, lipid or carbohydrate began to play an increasing role as winter progressed. A similar profile of gradually rising O:N ratio under prolonged starvation has also been recorded for other polar invertebrates, e.g. the limpet Nacella concinna (Clarke et al. 1994). Proximate composition estimated stoichiometrically from tissue elemental ratios ( $\mathrm{C}: \mathrm{H}: \mathrm{N})$ showed that both gut and gonad tissue were dominated by protein (54.7 and $40.9 \%$ respectively) (Brockington et al. 2001). Gut tissue also showed notably high concentrations of lipid (17\%), and this tissue also underwent the greatest loss in mass during winter relative to its initial pre-winter value. Gonad was also found to contain $24 \%$ lipid and $15.8 \%$ carbohydrate at the start of winter, and it is likely that both gut and gonad tissue supplied energy to fuel metabolism during the non-feeding period.

\section{Conclusion}

The metabolic rate of Sterechinus neumayeri shows a strong seasonality and is correlated to the intense summer phytoplankton bloom development rather than to seawater temperature. The respiratory rate is one of the lowest recorded for regular echinoids. This reduced rate may be of importance in allowing efficient usage of body reserves during the extended nonfeeding period of the austral winter. The sea urchin's seasonal factorial aerobic scope is comparable with aerobic scopes recorded for other Antarctic marine invertebrates. Because of the low basal aerobic rate, this indicates a constraint on the total power that may be generated in comparison to species from lower latitudes. The O:N ratio indicates that although protein is the main metabolic substrate, lipid and carbohydrate become more important as winter progresses. A sharp decrease in O:N ratios to around 7 indicates a change to a $100 \%$ protein-based metabolism at the onset of the summer season.

Acknowledgements. Special thanks are due to all the members of the Rothera Station between 1997 and 1999 who helped with the fieldwork, especially diving officers Rob Wood and Steve Dunkerley, and boatmen Stuart Wallace and Ian McDonald. Alice Chapman gave extensive help with both the SCUBA collections and laboratory work throughout the entire study period, and Iain Staniland helped with statistical analysis of results. Andrew Clarke provided guidance with experimental protocols and constructive criticism of the manuscript. John Lawrence, William B. Stickle Jr and 2 further anonymous referees also provided helpful criticism during the refereeing process prior to publication.

\section{LITERATURE CITED}

Ahn IY, Shim JH (1998) Summer metabolism of the Antarctic clam, Laternula elliptica (King and Broderip) in Maxwell Bay, King George Island and its implications. J Exp Mar Biol Ecol 224:253-264

Barnes DKA, Clarke A (1994) Seasonal variation in the feeding activity of four species of bryozoan in relation to environmental factors. J Exp Mar Biol Ecol 181:117-133

Barnes DKA, Clarke A (1995) Seasonality of feeding activity in Antarctic suspension feeders. Polar Biol 15:335-340

Bathmann U, Fischer G, Müller PJ, Gerdes D (1991) Shortterm variations in particulate matter sedimentation off Kapp Norvegia, Weddell Sea, Antarctica: relation to water mass advection, ice cover, plankton biomass and feeding activity. Polar Biol 11:185-195

Bayne BL, Scullard C (1977) Rates of nitrogen excretion by species of Mytilus (Bivalvia: Mollusca). J Mar Biol Assoc UK 57:355-369

Belman BW, Giese AC (1974) Oxygen consumption of an asteroid and an echinoid from the Antarctic. Biol Bull 146: 157-164

Bodungen B, Smetack VS, Tilzer MM, Zeitzschel B (1985) Primary production and sedimentation during spring in the Antarctic Peninsula region. Deep-Sea Res 33:177-194

Bookbinder LH, Shick JM (1986) Anaerobic and aerobic energy metabolism in ovaries of the sea urchin Strongylocentrotus droebachiensis. Mar Biol 93:103-110

Brafield A, Llewellyn M (1982) Animal energetics. Blackie, Glasgow

Brey T, Rumohr H, Ankar S (1988) Energy content of macrobenthic invertebrates: general conversion factors from weight to energy. J Exp Mar Biol Ecol 117:271-278

Brockington S, Clarke A (2001) The relative importance of temperature and food on the metabolism of a marine invertebrate. J Exp Mar Biol Ecol (in press)

Brockington S, Clarke A, Chapman ALG (2001) Seasonality of feeding and nutritional status during the austral winter in the Antarctic sea urchin Sterechinus neumayeri. Mar Biol (in press)

Catalano G (1987) An improved method for the determination of ammonia in seawater. Mar Chem 20:289-295

Chapelle G, Peck LS (1995) The influence of acclimation and substratum on the metabolism of the Antarctic amphipods Waldeckia obesa (Chevreux, 1905) and Bovallia gigantea (Pfeffer 1888). Polar Biol 15:225-232

Clarke A (1988) Seasonality in the Antarctic marine environment. Comp Biochem Physiol B 90:461-473

Clarke A (1991) What is cold adaptation and how should we measure it? Am Zool 31:81-92

Clarke A (1993) Seasonal acclimatization and latitudinal compensation in metabolism: do they exist? Funct Ecol 7: 139-149

Clarke A (1998) Temperature and energetics: an introduction to cold ocean physiology. In: Pörtner HO, Playle R (eds) Cold ocean physiology. Cambridge University Press, Cambridge, p 3-32 (Soc Exp Biol Sem Ser 66)

Clarke A, Johnston NM (1999) Scaling of metabolic rate with body mass and temperature in teleost fish. J Anim Ecol 68: 893-905

Clarke A, Leakey RJG (1996) The seasonal cycle of phytoplankton, macronutrients and the microbial community in a nearshore Antarctic marine ecosystem. Limnol Oceanogr 41:1281-1294

Clarke A, Peck LS (1991) The physiology of polar marine zooplankton. Polar Res 10:355-369

Clarke A, Holmes LJ, White MG (1988) The annual cycle of 
temperature, chlorophyll and major nutrients at Signy Island, South Orkney Islands, 1969-82. Br Antarct Surv Bull 80:65-86

Clarke A, Prothero-Thomas E, Whitehouse MJ (1994) Nitrogen excretion in the Antarctic limpet Nacella concinna (Strebel, 1908). J Molluscan Stud 60:141-147

Davenport J (1988) Oxygen consumption and ventilation rate at low temperatures in the Antarctic protobranch bivalve mollusc Yoldia (= Aequiyoldia) eightsi (Courthouy). Comp Biochem Physiol A 90:511-513

Davoult D, Gounin F, Janquin MA (1991) Ammonium excretion by the ophiuroid Ophiothrix fragilis as a function of season and tide. Mar Biol 111:425-429

Dell RK (1972) Antarctic benthos. Adv Mar Biol 10:1-216

Féral JP, Magniez P (1988) Relationship between rate of oxygen consumption and somatic and gonadal size in the subantarctic echinoid Abatus cordatus from Kerguelen. In: Burke RD, Mladenov PV, Lambert P, Parsley RL (eds) Echinoderm biology. Proceedings of the Sixth International Echinoderm Conference. AA Balkema, Rotterdam

Graf G (1992) Benthic-pelagic coupling: a benthic view. Oceanogr Mar Biol Annu Rev 30:149-190

Guderly H (1998) Temperature and growth as modulators of the metabolic capacities of fish muscle. In: Portner HO, Playle R (eds) Cold ocean physiology. Society for Experimental Biology seminar series 66. Cambridge University Press, Cambridge, p 58-87 (Soc Exp Biol Sem Ser 66)

Ikeda $T$ (1977) The effects of laboratory conditions on the extrapolation of experimental measurements to the ecology of marine zooplankton. IV. Changes in respiration and excretion rates of boreal zooplankton species maintained under fed and starved conditions. Mar Biol 41:241-252

Ikeda T, Hing Fay E (1981) Metabolic activity of zooplankton from the Antarctic Ocean. Aust J Mar Freshw Res 32: 921-930

Jangoux M (1982) Excretion. In: Jangoux M, Lawrence JM (eds) Echinoderm nutrition. AA Balkema, Rotterdam

Johnston IA, Guderly HE, Franklin CE, Crockford T, Kamunde C (1994) Are mitochondria subject to evolutionary temperature adaptation? J Exp Biol 195:293-306

Johnston IA, Calvo J, Guderley H, Fernandez D, Palmer L (1998) Latitudinal variation in the abundance and oxidative capacities of muscle mitochondria in perciform fishes. J Exp Biol 201:1-12

Karl DM, Tilbrook BD, Tien G (1991) Seasonal coupling of organic matter production and particle flux in the western Bransfield Strait, Antarctica. Deep-Sea Res 38(8/9, RACER):1097-1126

Lares MT, Pomory CM (1998) Use of body components during starvation in Lytechinus variegatus (Lamarck) (Echinodermata: Echinoidea). J Exp Mar Biol Ecol 225:99-106

Liddicoat MI, Tibbits S, Butler EI (1975) The determination of ammonia in seawater. Limnol Oceanogr 20:131-132

Luxmoore RA (1984) A comparison of the respiration rates of some Antarctic isopods with species from lower latitudes. Br Antarct Surv Bull 62:53-65

Mayzaud P, Conover RJ (1988) Review: O:N atomic ratio as a

Editorial responsibility: John Lawrence (Contributing Editor), Tampa, Florida, USA tool to describe zooplankton metabolism. Mar Ecol Prog Ser 45:289-302

McClintock JB (1994) Trophic biology of Antarctic shallow water echinoderms. Mar Ecol Prog Ser 111:191-202

Pearse JS, Giese AC (1967) Food, reproduction and organic constitution of the common Antarctic echinoid Sterechinus neumayeri (Meissner). Biol Bull 130:387-401

Peck LS (1989) Temperature and basal metabolism in two Antarctic marine herbivores. J Exp Mar Biol Ecol 127:1-12

Peck LS (1996) Metabolism and feeding in the Antarctic brachiopod Liothyrella uva: a low energy lifestyle species with restricted metabolic scope. Proc R Soc Biol Sci Ser B 263:223-228

Peck LS (1998) Feeding, metabolism and metabolic scope in Antarctic marine ectotherms. In: Pörtner HO, Playle R (eds) Cold ocean physiology. Cambridge University Press, Cambridge, p 365-390 (Soc Exp Biol Sem Ser 66)

Peck LS, Conway LZ (2000) The myth of metabolic cold adaptation: oxygen consumption in stenothermal Antarctic bivalves. In: Harper EM, Taylor JD, Crame JA (eds) Evolutionary biology of the Bivalvia. Geological Society, London (Spec Publ)

Peck LS, Uglow RF (1990) Two methods for the assessment of the oxygen content of small seawater samples. J Exp Mar Biol Ecol 141:53-62

Peck LS, Clarke A, Holmes LJ (1987) Summer metabolism and seasonal changes in biochemical composition of the Antarctic brachiopod Liothyrella uva (Broderip, 1833). J Exp Mar Biol Ecol 114:85-97

Pörtner HO, Hardewig I, Sartoris FJ, van Dijk PLM (1998) Energetic aspects of cold adaptation: critical temperatures in metabolic, ionic and acid-base regulation. In: Pörtner HO, Playle R (eds) Cold ocean physiology. Cambridge University Press, Cambridge, p 88-120 (Soc Exp Biol Sem Ser 66)

Pörtner HO, Peck L, Zielinski S, Conway LZ (1999) Intracellular $\mathrm{pH}$ and energy metabolism in the highly stenothermal Antarctic bivalve Limopsis marionensis as a function of ambient temperature. Polar Biol 22:17-30

Ralph R, Maxwell JGH (1977) The oxygen consumption of the Antarctic lamellibranch Gaimardia trapesina trapesina in relation to cold adaptation in polar invertebrates. Br Antarct Surv Bull 45:41-46

Rivkin RB (1991) Seasonal patterns of phytoplanktonic production in McMurdo Sound, Antarctica. Am Zool 31:5-16

SAS Institute Inc. (1998) Version 6.12. SAS Institute Inc., Cary, NC

Solórzano L (1969) Determination of ammonia in natural waters by the phenol-hypochlorite method. Limnol Oceanogr 14:799-801

Stickle WB (1988) Patterns of nitrogen excretion in the phylum Echinodermata. Comp Biochem Physiol 91A:317-321

White MG (1975) Oxygen consumption and nitrogen excretion by the giant Antarctic isopod Glyptonotus antarcticus Eights in relation to cold adapted metabolism in marine polar poikilotherms. In: Barnes H (ed) Proceedings of the Ninth European Marine Biological Symposium. Aberdeen University Press, p 707-724

Submitted: July 15, 2000; Accepted: December 13, 2000

Proofs received from author(s): August 13, 2001 